\title{
Durkheim’s Sign Made Flesh: The “Authentic Symbol” in Contemporary Holocaust Pilgrimage
}

\author{
Natalie C. Polzer
}

Abstract: Synthesizing Durkheim's notion of "sacred symbol" with Walter Benjamin's theorization of "authenticity," this paper proposes the theoretical construct, "authentic symbol," to account for the symbolic function of Holocaust relics in contemporary Holocaust pilgrimage. The symbolic function of four kinds of relics (the sites, witness/survivors, human bodily remains and accessories) is examined and compared in three different contexts: The March of the Living Holocaust tours organized for Diaspora Jewish teenagers, the Masa tours organized for Israeli teenagers and the U.S. Holocaust Museum in Washington D.C. Different ritual experiences are found to predominate in each of the three contexts, which significantly correlate with how symbols are processed by participants and the different ideological and practical aims of the tours and displays.

Keywords: Holocaust tours, symbols, relics, authenticity

Résumé: Résumé. Employant un synthèse de la notion Durkheimienne de "symbole sacrée" avec la théorisation de Walter Benjamin au sujet de "l'authenticité," cet article propose une construction théorique nouvelle, "symbole authentique," pour expliquer la fonction symbolique des reliques de la Shoah dans les pèlerinages contemporains vers les sites du Holocauste. La fonction symbolique de quatre types de reliques (les sites-mêmes, les témoins/survivants, les débris humains et les accessoires) est considérée et comparée en trois contextes différents: les visites "Marche des vivants" organisées pour les adolescents juifs du diaspora, les visites Masa organisées pour les adolescents israéliens et le musée de la Shoah à Washington, D.C. Chaque contexte offre une expérience rituelle prédominante et différente, ce qui corrèle au traitement des symboles par les participants et les buts différents et idéologiques et pratiques de chacun des visites et des expositions.

Mots clés: pèlerinages du Holocauste; symboles; reliques; l'authenticité 


\section{INTRODUCTION}

1 s religion is an "eminently "social thing," in which "...the quality of 【sacredness..." is the observable product of collective doing" (Fields 1995: xxxiv), the components of religious life change along with the structural and ideological exigencies of societies. In The Elementary Forms of Religious Life (EFRL), Émile Durkheim (1858-1917) predicted that religions and their symbols would transform to meet future social needs when "...new ideals...[will] emerge to guide humanity... in future...hours of creative effervescence" (EFRL: 429-430). Indeed, Durkheim, the French republican advocate of universal individual rights (Fournier 2007: 370, 376-378), had witnessed in his own day “.... a new kind of...international [social] life [in which]...society no longer appears as the whole, par excellence, and becomes part of a whole that is more vast, with frontiers that are indefinite..." (EFRL: 446). Remarking on this process concerning the Jewish Diaspora's current relationship with the State of Israel, Nadine Blumer notes that "...the globalizing principle of transnationalism... de-emphasizes the link between collective identity formation and geography... [and] redefines the nation-state as a more permeable entity that does not delimit the boundaries of social relations" (2011: 1332).

This analysis of contemporary Holocaust pilgrimage confirms the ongoing theoretical relevance of EFRL by showing a transformation of the nature of symbols in transnational contexts. It is notable that no universal symbol has evolved for the Holocaust, defined as "...the mass murder by the Nazis of the Jews of continental Europe between 1940 and 1945" (Hanks ed. 1986: 731), but the word itself, which transmits "...all the protocols of the unspeakable, the incommensurate, and a sense of unlimited scope to the pain and injustice" (Patranka 1997: 55). The demand for the "authenticity" of Holocaust relics requires a more adequate theoretical construct, developed here as the "authentic symbol," to designate a configuration of the sacred symbol. This concept synthesizes Durkheim's definition in EFRL (1912) with Walter Benjamin's notion of authenticity (1924). For Durkheim, sacred symbols have a critical function in the creation and perpetuation of social cohesion: they both inscribe and evoke collective representations and keep them "perpetually alive and fresh" since "[they]...live... beyond the gathering," that is, motivating individuals long after the dispersion of the congregation in which their "mysterious force" was originally felt (EFRL: 222).

Modern transnational social structures and traumatic historical events, such as the Holocaust, have apparently made new demands on the concept of "the sacred." Notably, Giorgio Agamben has recently 
theorized a novel notion of "sacred man," homo sacer, of which the Jewish victims of Nazi extermination camps are his paradigmatic example (Agamben 1998). For Agamben, homo sacer signifies the reduction of the individual human to "bare life," a state in which the historically distinct biological and social aspects of human life intermesh in "a state of indistinction" that corresponds to a form of inclusive exclusion typified by the political/juridical practices of the ban or the exception (ibid.: 181). Rejecting Durkheim's cognitively based notion of the sacred as emotive and reductionist (ibid.: 77-78) and, apparently, ignoring the intensive, ongoing response to the Holocaust's symbolic power in the contemporary West, he polemically refuses to accord any "sacral aura" to the Holocaust, chastising those who do (ibid.: 114). Significantly, Agamben's conception of homo sacer correlates with the authentic symbol, suggesting that both are examples of a singular phenomenon in different realms of human experience, the political and the religious respectively. Certainly both notions reduce ideological/ social aspects of human life to a material basis, fusing two historically distinct domains of human experience - for Durkheim, the profane/individual and the sacred/social; for Agamben, man's social and political life ("bios") and his bare biological existence ("zoe") (ibid.: 2-3).

\section{The Genealogy of the Authentic Symbol}

The term "authentic symbol" designates a reified symbol, exemplified here by Holocaust sites and other relics. Documentation universally, yet unreflectively, insists that Holocaust relics must be "authentic" to be considered functional sacred symbols that evoke and internalize appropriate ideological collective response (Blumer 2010; Bodemann 2006; Cole 1999; Feldman 2008; Weinberg and Elieli 1995). Hence, the symbolic power of Holocaust relics is perceived as inhering in their intrinsic empirical and historical attributes. The notion of the "authentic symbol" problematizes one of Durkheim's most critical theoretical tenets. In Durkheim's view, the symbol is a central, "abiding element of social life," defined as the image or object that "...calls forth those [socially significant] emotions even after the assembly (i.e., a shared collective experience generating social effervescence) is over" (EFRL: 222-223). The symbol perpetuates collective cohesion cognitively by transcending actual social relations or physical proximity. Although the authentic symbol functions in the same way, it is inadequately captured by Durkheim's distinction between the realms of "the profane" and "the sacred" (EFRL: 36-37), which he identifies with the inherently irreducible dualism of 
individual and collective human cognition (EFRL: 15; Shilling 2005: 217-222), even if synthesized by the meeting of individual and collective representations in the minds of individuals. Durkheim distinguishes between two distinct domains of physical and mental human experience: "profane" activity, instrumental for the perpetuation of physical human life and achieved at the level of individual sensory perception and rational processing, and "sacred" activity perpetuating social solidarity through cognitively shared, symbolic collective representations (EFRL: 216-217; Fields 1995: xliii-xlv).

Corresponding to the irreducibility of individual and collective modes of cognition is the irreducibility of the signifier and the signified. According to Durkheim, “...[t] he sacredness exhibited by the thing is not implicated in the intrinsic properties of the thing: It is added to them. The world of the religious is not a special aspect of empirical nature: $I t$ is superimposed upon nature" (EFRL: 230). Thus, the sacred power or meaning perceived as immanent in a symbolic object cannot inhere in its empirical characteristics or be accessible to individual sensory perception, requiring the effervescent crucible of collective experience to be rendered apparent (EFRL: 126, 220-222, 231-235). Durkheim considered the peculiar sacredness of relics to illustrate this distinction between sacred/collective and profane/individual:
A fragment of a relic has the same virtues as the whole relic..., [so] from the standpoint of religious thought, the part equals the whole... [with] the same powers and the same efficacy.... This conception would be inexplic- able if sacredness depended on the constitutive properties of the thing serving as its substitute, for sacredness would have to change with that thing, increasing and decreasing with it (EFRL: 230-231).

The authentic symbol, however, requires a more nuanced application of Durkheim's distinction between sacred and profane, for the precise historical identity of an authentic symbol and its material/empirical integrity is a requirement for invoking an authentic symbolic experience.

The current status of the authentic symbol may be understood as the result of the much debated historical uniqueness of the Holocaust which arguably forced a traumatic shift in human powers of symbolization. Epitomized by Theodor Adorno's canonical aphorism, "to write poetry after Auschwitz is barbaric" (cited in Rothberg 2000, 19), this position alleges that the Holocaust's unprecedented horror caused a traumatic break in human cognitive capacity (ibid.: 19-27). The trauma demanded a shift towards an empirically based symbolism of "traumatic realism" (ibid.), which can only generate collective response by virtue of its intrinsic empirical qualities, well exemplified by the prevailing emphasis 
on the utilitarian function of authentic Holocaust relics, namely, to refute anti-Semitism and Holocaust denial. Thus, the search for artifacts for the U.S. Holocaust Museum in Washington, D.C. “... was informed by the decision that the exhibition should include only historically authentic material, as opposed to reproductions... [owing to] ...the activities of Holocaust deniers" (Weinberg and Elieli 1995: 57; Lipstadt 1993). Here, the artifact's historical testimony is, paradoxically, simultaneously reified and sacralized; the "correct" version of history is not simply a plausible interpretation of the past, but is empirically immanent in the artifacts themselves, which become transcendent, ideologically charged witnesses.

The authentic symbol may well be part of a longer historical trajectory, the gradual transformation of Western societies from coherent communities, clearly defined by geographical, social and ideological boundaries, into the "imagined communities" of the post-Enlightenment nation state. In such communities, the citizens of "...even the smallest nation" will never engage in actual social relations with "most of their fellow members, ...yet in the minds of each lives the image of their communion" (Anderson 2004: 6). What Blumer calls the "...globalizing principle of transnationalism" (2011: 1332) encourages the development of collective representations of national cohesion, which transcend discrete social structures and geographical territories. The increasingly abstract nature of social cohesion, realizable only as "communities of the imagination" rather than in actual social praxis, may well require a compensating shift at the level of symbolization, demanding the empirical authenticity of functional symbols.

\section{BenJamin's "Aura" and Durkheim's "SACRED"}

That the authentic symbol is a general symptom of Western modernity is supported by the fact that authenticity is a prevalent theme in recent general scholarship on tourism and museum studies (Baldwin and Sharpely 2009; Bruner 1994; Holtschneider 2011; Horne 1984; MacCannell 1999; Sharpely and Stone 2009). Moreover, the theorization of authenticity predates the Holocaust, most notably, in the work of Walter Benjamin (1892-1940). In his classic essay, "The Work of Art in the Age of Its Technological Reproducibility," Benjamin theorizes the "aura," a quality inherent in a work of art that renders it unique and hence culturally authoritative. He describes the elusive, yet immanent, aura as a "... strange tissue of space and time: the unique apparition of a distance, however near it may be..." (Benjamin 2008 [1936]: 23). Equating the 
"aura" with "authenticity," he isolates two requisite characteristics of an object possessing an "aura." First, its material/empirical characteristics must evidence its "core," its "unique existence... bear[ing] the mark of the history to which... [it] has been subject" (ibid.: 21-22). Second, an authentic artifact is conferred with a specific authority by the culture to whose unique history it testifies (ibid.: 22). According to Benjamin, traditional aesthetics considered the authoritative "aura" to inhere only in an original object; in reproductions its power is compromised or null (ibid.: 21-23; Jennings 2008: 14-15).

Authentic symbols function as sacred symbols in the Durkheimian sense, since they evoke and perpetuate collective representations in a ritualized context, thereby affecting and perpetuating collective union. However, in line with Benjamin's concept of authenticity, their empirical qualities and historical experience determine their ability to provoke an authoritative symbolic response. Benjamin's elusive aura echoes Durkheim's concept of sacred power, which, in its manifestation as totemic principle, he deems a "diffuse and anonymous force" (EFRL: 197) that “...cannot be defined by specific attributes and qualities" (EFRL: 195). To simplify a comparison worthy of much more detail, both "the aura" and "the sacred" are relative, collectively conferred, abstract forces that are deemed to be inherent in objects and that render them effective symbols, capable of representing and eliciting a culturally normative response. Moreover, both Durkheim and Benjamin insist that the abstract force of sacredness or aura is conferred during religious ritual (Benjamin 2008 [1936]: 24; EFRL: 420-422). However, Durkheim's "sacred" and Benjamin's "aura of authenticity" differ critically in one respect. Whereas Durkheim's "sacred" is a sociological construct describing the cognitive mechanism of collective ideological cohesion, Benjamin's "aura of authenticity" is aesthetic and individualistic and not concerned with the constitution and reconstitution of social cohesion.

\section{Contemporary Holocaust Pilgrimage}

The Holocaust has stimulated a variety of national and transnational ideological responses exemplified by the types of Holocaust pilgrimage reviewed here. This paper considers ethnographic (Feldman 2008) and sociological (Blumer 2011; Bodemann and Korn 2006) studies, and media discourse describing or promoting two Holocaust pilgrimage destinations: the concentration camps, especially Auschwitz/Birkenau, and the Washington D.C. Holocaust Museum. Three distinct groups of Holocaust pilgrims are isolated for analysis: Jewish Israeli teenagers (the 
Masa Holocaust tours facilitated by the Israeli Ministry of Education hereafter, Masa), Diaspora Jewish teenagers (the March of the Living tours facilitated by the World Jewish Zionist Organization - hereafter, MOL) and a largely secular American public at large (the Washington D.C. Holocaust Museum). Significantly, despite their differences, the three groups all demand authentic symbols in order to elicit and inscribe participants" normative ideological experience.

Whereas the U.S. Holocaust Museum promotes specifically American ideologies of pluralism and tolerance to a general American public, the two Holocaust tours instill Zionist ideologies peculiar to Israeli and Diasporic Jewish collectives. The Holocaust's role in promoting nationalist allegiances remains controversial. Jewish community institutions worldwide praise Holocaust tours for effectively eliciting support for the State of Israel (Feldman 2008: 58-60), but their alleged stimulation of an unreflective Zionist response has prompted critics to consider them a form of "nationalistic brainwashing" (cited in ibid.: 2008, 20; 15-16, 60). Accordingly, the symbolic merging of the Holocaust, Zionist ideologies and the practical needs of the State of Israel is seen as a simplistic blurring of past and present European anti-Semitism with the current relationship between Jewish Israelis and Israeli-Arab and Palestinian populations (ibid.: 274-275), that encourages anti-Arab sentiment among Jewish youth (ibid.: 122, 152, 154). Likewise, the U. S. Holocaust Museum has been criticized for its alleged exploitation of Nazi genocide to confirm exclusively American nationalistic ideologies (Linenthal 1995: 255-272).

\section{Holocaust Tourism/Pilgrimage}

The many Western tourist attractions constituting "Dark Tourism" battlefields, disaster sites and cemeteries - show that the contemporary concern for authenticity is scarcely restricted to the Holocaust (Sharpley and Stone 2009: 116-118). Visitors to these sites seek the meaningfulness that accompanies the contemplation of authentic remains (Baldwin and Sharpley 2009; Beech 2009). Contrary to the assumption that "the tourist" seeks out meaningless leisure entertainment, destinations are often chosen for ideological reasons (Sharpely and Stone 2009: 116). Indeed, tourism is often a religious activity, in the Durkheimian sense, through which tourists seek the emotionally charged experience of identification with collective ideologies through the physical proximity of an authentic relic of the past. 
Despite an insistence that visits to Holocaust sites should always be reverent pilgrimage rather than casual tourism, there is little critical reflection on the difference between the two. David Horne's classic study of the modern museum confounds the categories, calling Auschwitz visitors “...tourists on a horror pilgrimage..." (1984: 243-244). Others sharply distinguish Auschwitz as "... a site of mass tourism and a site of pilgrimage" (Cole 1999: 116). Tim Cole assumes, yet never critically addresses, a radical moral dichotomy between the Holocaust pilgrim/ Holocaust tourist, in which pilgrimage is laudable and tourism deplorable (ibid.). He fails to see any ideologically respectable motivation in the Holocaust tourist, calling Auschwitz, a "theme park," offering entertainment through ostentatious displays of gruesome "authentic relics" (ibid.: 110-111). Website accounts also express frequent anxiety over casual Holocaust tourism (Brueggman 2001), best epitomized by Guy Rundle who eloquently deplores the callousness of the "...beefy, lolling German tourists" occupying a decaying Auschwitz (2007).

Durkheim's understanding of the equivalence of sacred-collective and profane-individual, helps one distinguish between three ideal types: the casual tourist, the ideologically motivated tourist and the pilgrim, each distinguished by their ideological identification with the destination site and by their cohesion with a distinct social group, implicated in the site and what it represents. A casual/profane tourist has little ideological investment and/or social relationship with the target destination. For such a tourist, Auschwitz may prompt a strong response without evoking collective ideologies, exemplified by the following description: "In Room 5 of Block 4, there is a huge glass display case...filled with hair cut from the heads of an estimated 140,000 victims... deteriorating badly.... This is a truly disgusting sight..., one that a visitor won't soon forget" (Auschwitz Museum Exhibits 2009). An ideological tourist chooses the target destination because of its ideological force, expecting a meaningful experience through proximity to its symbolic power. In this case, the visitor might share the ideological rationale for the display, without identifying with or being part of a particular social group implicated in the site. A "pilgrim" is distinct from an ideological tourist by social constituency in a population collectively implicated in the target destination.

\section{Mol AND MASA}

Judaism is no stranger to embodied symbolism; indeed, recent scholarship confirms a more than 2500 year long, historical trajectory of the centrality of symbols of the body in Jewish religious and social prac- 
tice (Eilberg-Schwartz 1992; Biale 2007), a trajectory in which, judging from recent scholarship, arguably Durkheim himself might be counted (Shilling 2005; Friedland 2005). Consider this image appearing in a video recording of a MOL Auschwitz pilgrimage, which merges a causal relationship between anti-Semitism and Zionism in an embodied, symbolic representation of Jewish continuity. Two naked human arms, cut off at the elbow, reach out, the smaller resting on the larger in midscreen against the unifying backdrop of the blue and white Israeli flag. One arm, wrinkled, elderly, obviously male, bears a crude tattoo of six numbers; the other arm, plump, fresh, and androgynous, is a toddler's (March of the Living May 2, 2011-12: 39-41). Flesh overlaps flesh; identity, identity. Jewish bodies themselves become authentic symbols of the Jewish historical paradigm of suffering and redemption through national continuity, represented through the juxtaposition of anti-Semitism and Zionism (the tattooed arm and the Israeli flag). The overlapping elderly and infant Jewish flesh suggests the "ritual of replacement," which will be argued later for the MOL tours, through which contemporary Diaspora Jewish youth replace dead Holocaust victims with their living, Jewish bodies.

A simple "holocaust tours" Google search illustrates how "pilgrimage" tours to the Nazi death camps have become a lucrative staple of Jewish identity tourism. The MOL and the Masa tours are no exception, although their gain is not financial profit but ideological and social capital. The two tours evidence nuanced, significant differences in their ideological agenda and ritual experience, reflecting the different practical and ideological needs of Diaspora and Israeli communities. The MOL tours (March of the Living International) targeting Diaspora Jewish teenagers were begun by Birthright Israel ${ }^{1}$ in 1988 (Blumer 2011; Feldman 2007: 138; Cole 1999: 117), and have since become a requisite "rite of passage for many Jewish youth around the world" (Blumer 2011: 1334). The tour is orchestrated so that Jewish teenagers from "free and democratic countries...come face-to-face with... [the] venom [of anti-Semitism] they had not previously known" to learn to appreciate "[t]he extraordinary achievement of Israel" (Michael Berenbaum, cited in Shevelev and Schomer 1996: viii-ix). Judging from video coverage and participants" testimonials (Grunfeld-Grossman 2006; Shevelev and Schomer 1996), this carefully planned, ritualized tour is a text book example of Durkheim's "positive cult," a powerfully "...effervescent social milieu" (EFRL: 220) caused by transition from profane to sacred space, in which "collective emotion" is expressed in "gestures... [of] rhythm and regularity" causing "an intense hyperexcitement of physical

1. http://birthrightisrael.org 
and mental life" on the part of the participants (EFRL: 218), resulting in social cohesion through the internalization of collective representations of identity and nationalism.

The tour's ability to provoke collective cohesion is aided by the volatile, contagious emotional exuberance of the thousands of teenaged participants. Synchronized with the Jewish ritual calendar, groups from all over the world fly to Poland just after Passover, touring for five days before converging upon the Birkenau-Auschwitz complex on Holocaust Memorial Day. The centerpiece of the day is a ritualized mass march between the two camps, initiated by the call of the ram's horn (a Jewish symbol evoking attention, repentance and transformation). The march is a conscious re-enactment of " $\ldots$ the journey that the victims of the Holocaust were forced to endure in order to arrive at the Birkenau concentration camp" (Grunfeld-Grossman 2006: 109). This orchestrated re-enactment constitutes a "ritual of replacement," through which living Diaspora Jewish teenagers symbolically replace Holocaust victims in the very location of their slaughter. Through this ritual process, including confrontation with Holocaust relics, collective commitment to two distinct, ambivalent locations of Jewish identity deemed necessary to Jewish survival are internalized: (1) a thriving Jewish presence in the Diaspora; and, (2) an affirmation of the centrality of the State of Israel to the survival of Diaspora Jewish life and identity (Blumer 2010). After five days in Poland, participants fly to Israel to celebrate a similarly orchestrated Israeli Independence Day in the Jewish State.

Under the aegis of the Israeli Ministry of Education, the first Masa tours also took place in 1988 (Feldman 2008: 57-58). While the eight day tour's itinerary and experiential orchestration ostensibly replicates a "significant pilgrimage path," (ibid.: 77), Masa's goals are explicitly patriotic: "We assume that pupils will return from this voyage with stronger links to the history of Israel and its heritage, firmer and more determined to build and assure ...the future of the State, and be prepared to mobilize to contribute their share... to guard[ing... its] future..." (ibid.: 58). Feldman identifies the Masa tours as "rituals of ordeal" (ibid.: 62-63). The ordeal element is embodied in participants" experiencing the "element of danger" of being among "a hostile population," namely, the contemporary Polish Diaspora environment with its historical evidence of anti-Semitism (ibid.: 62-63, 121-123). Through this ritualized ordeal, Israeli teenagers symbolically survive "...the precarious nature of Jewish existence" (ibid.: 59). Experiencing "survival by proxy," their commitment to the State is strengthened in anticipation of compulsory 
service in the Israeli Defense Force after graduation from high school (ibid.: 3, 245-246). The emphasis on ordeal and danger renders Masa tours examples of Durkheim's "rituals of pain." Durkheim claims a sanctifying, that is a socializing, force in voluntarily suffered pain and/or bodily privation, effecting repression of individual thought and the subsequent submission of the individual mind to collective beliefs ( $E F R L$ : 320). Calling such ritual practices the "negative cult," Durkheim deemed them to be present in all religions, necessary preliminaries for effective integration of collective ideologies (EFRL: 314-21).

As rites of passage, both MOL and Masa incorporate aspects of the effervescent congregation of the "positive cult" and the rituals of pain of the "negative cult," yet the former predominates in MOL and the latter, in Masa. That is, in MOL tours Diasporic Jewish teenagers engage in a predominantly positive experience of group bonding and energizing ideological cohesion, whereas Masa tours encourage negative experiences of isolation, dread and ordeal. Thus, the two tours inculcate two distinctive Zionist ideologies and resulting forms of practical commitment to the Jewish State. MOL participants are expected to integrate an ambivalent "homeland trope" in which the "state of Israel is articulated as the anchoring point" of Jewish survival, yet in which the state requires the ongoing financial and political support of Diasporic Jews, confirming both the validity of "...ethno-diasporic consciousness and solidarity" and the priority of the State of Israel (Blumer 2011: 1334-1335, 1339). $M a s a$ 's goal of preparing Israeli teenagers for future military service requires the isolating, painful, ritual experience of ordeal, (Feldman 2008: 243-248) as the negative encounters (real or imagined) with the Poland environment and its anti-Semitism may be transferred to the Arab- Israeli conflict (ibid.: 244, 274). Moreover, the ordeal experience prompts Israeli teenagers to distance themselves emotionally and ideologically from the Holocaust victims and the sites in which they perished, and, by extension, from the authenticity of Diasporic Jewish experience, a distancing which, arguably, subtly maintains the problematic suppression of the Holocaust and denigration of Holocaust victims, a feature of Israeli society up to the mid 1960's (ibid.: 31-32).

\section{The Relic as Authentic Symbol}

Four types of relics constituting authentic symbols for Masa and MOL participants will be examined next: (1) the sites; (2) Holocaust survivors; (3) human bodily remains; and, (4) accessories. 


\section{The Sites}

The literature unanimously asserts that a full experience of Holocaust atrocities can only be achieved at the actual sites on which they occurred. This impression is re-iterated in one MOL participant's testimony: "You must see the real thing to understand" (Weintraub, n.d. March of the Living: the Only Choice). Another participant exclaims in teenaged idiom: "It was cold and rainy and the clouds were overlooking us as we were going from Auschwitz-Birkenau....... [A]ctually standing there was one of the most unreal moments of my life" (Grunfeld-Grossman 2006: 85). While the valorization of authentic sites is a standard feature of "genocide tourism" (Beech 2009), it has a particular function in the MOL. MOL attempts to induce the experience of anti-Semitism by physically surrounding participants with the actual structures erected by the Nazis to facilitate Jewish extermination (Berenbaum, cited in Shevelev and Schomer 1996: viii-ix). Participants attest to the effectiveness of this strategy, for instance: "...Majdanek [was] the most haunting of all the camps... visited... because it was so well preserved it could be operational given sixteen hours notice" (Shevelev and Schomer 1996: 53).

Yet, the MOL pilgrimage does not result in the internalization of a negative, fatalistic identification with the victims of anti-Semitism. Rather, Jewish Holocaust victims become assimilated to the living Jewish youth through a ritual of replacement, constituting a collective victory over Nazi oppression, as every Holocaust Memorial Day, Auschwitz is again full of living Jews. Not shaved, starving victims in gray and white, shabby pajamas, but exuberant, youthful Jews sporting uniform "striking blue jackets" (Grunefeld-Grossman 2006). The numerous MOL YouTube videos illustrate this ritual of replacement, showing the throngs of Jewish teenagers emoting, praying, singing, dancing, and marching, with the Auschwitz complex as the backdrop. Thus, the dead victims are symbolically assimilated into a living corporate body, energized by the collective ideological obligation of the living to the dead. A participant reflects: "We marched, six thousand of us, in...identical blue jackets.... We walked for them, the six million who were massacred simply for being Jewish" (Shevelev and Schomer 1996: 104). And after the effervescent "Auschwitz moment," young Diasporic MOL participants can continue their sacred obligation to the dead by ongoing commitment to Diasporic Jewish life and to the State of Israel.

While Israeli teenagers also participate in the mass march on Holocaust Memorial Day, the overall ritual orchestration of the Masa tours differs from that of MOL. Most of the Masa trips are not synchronized with the Jewish liturgical calendar, in accordance with the participants' 
status as Israeli citizens who do not need the same experiential contrast between Auschwitz-Birkenau and Israel Independence Day in Israel to engender commitment to their state. In Masa tours, the "redemption" of the dead is effected by symbolically assimilating Holocaust victims and sites into the State of Israel by the ritual display of the Israeli flag, expressing a symbolic "rhetoric of manifesting presence" (Feldman 2008: 138-139; see also EFRL: 228, 229, 231). Feldman deems this ritual a symbolic conquest of territory with military overtones (ibid.: 193), a sort of retroactive territorial assimilation of the Diasporic past into the Israeli national present.

Feldman's ethnography suggests that Israeli teenagers demand a much higher level of authenticity from Holocaust remains than Diasporic Jewish youth, in order for them to function as effective symbols. During a Warsaw Ghetto Museum tour, one participant remarks: "I want to see concrete things, not just candlesticks that I can see anywhere" (ibid.: 105). A fragment of the Warsaw ghetto wall, "which can be touched and (so some visitors imagine) smelled, as well as seen" (ibid.: 106), is singled out as singularly impressive. Feldman contends that the impact of a site or relic is in direct correlation with the "thickness of its sensory envelope" (ibid.: 89). The more it is open to direct sensory experience, whether visual, acoustic or olfactory, the greater power it has as an authentic symbol. Feldman implies a hierarchy of the symbolic force of remains directly correlating with their openness to sensory experience. Masa participants regard Auschwitz I as difficult to process as "real" because it lacks direct sensory access: “...[T]he buildings are wellventilated; the objects have no smell and cannot be touched. A multisensory experience is essential to the students" experience of authenticity..." (ibid.: 140, 142). Significantly, no MOL evidence suggests that the exhibits in Auschwitz I were anything but authentic and impressive to Diaspora youth. Indeed, Feldman implies that there is some aspect of the Israeli identity that requires a more intensive sensory experience to prompt symbolic response, remarking: “...[F]or a people whose primary national-religious symbol is the Western Wall, a wall is a relatively easy object to sacralize" (ibid.: 106).

\section{The Survivors}

Holocaust survivors accompanying both tours are living authentic symbols, evoking and channeling participants' response (ibid.: 67-69). For MOL participants, the survivors elicit strong emotional responses, from fascinated awe to intense, personal attachment. The survivors' symbolic power is evident in participants' empathic responses to witnessing re-en- 
actment of their suffering in situ. For instance: "For this one...survivor it was her first trip back. All the kids were...clinging to her.... We wanted to watch her walk to Majdanek for the first time" (Grunfeld-Grossman 2006: 82). Another participant exhibits a strong emotional response: "I became very close to a survivor.... He was my strength.... I saw him crying for the first time [at Majdanek], it was really intense" (ibid.: 82). The symbolic power of both the survivor and the authentic site merge in a testimony of a survivor's "miracle": "She was determined to locate the exact spot where she last saw her family and there light her candle. ... $[\mathrm{S}]$ he struck her match, but the...wind blew out the flame.... [A]s a last attempt... she moved over one foot and lit her candle. The flame caught, fought the wind and... glow[ed] all day" (Shevelev and Schomer 1996: 108-109).

The symbolic role of the survivors in Masa tours appears to be much less personal and more formally ritualized. Most significantly, their oral testimonies are spatially contextualized, dependent upon the perceived authenticity of the site in which they are delivered. This contextualization reflects the ideological/geographical distancing of Israeli national present from Jewish Diaspora past. The survivors' scripted role correlates with the absence of expressions of a personal and/or emotional response by Masa participants. Here, the survivor-witness is not primarily an individual with whom to forge an emotional bond, but a formalized "symbolic type," bearing the significant title "man/woman of testimony" (Feldman 2008: 67, 66-69).

While survivors are granted supreme moral authority, to the point where they may "transmit... messages contrary to the aims of the organizers" (ibid.: 69), participants give their testimony full attention only in authentic campsites, where their storytelling is transformed into a sacred event (ibid.: 147-148). Feldman describes a survivor's trancelike recitation in Birkenau, "a potent death site," as "one of the most significant ritual moments" for participants, a reversion "back to the illum tempore (holy time) of the Shoah" (ibid.: 147). Significant for effecting distance between the Israeli present and the Diasporic past, many Masa participants don't remember the actual content of witness's stories, but only its chilling emotional effect (ibid.: 148). Moreover, when survivors tell their stories during bus rides through Poland, participants pay scant attention, often sleeping through their recitals (ibid.: 69). Claims Feldman: "Without the visual "here," this testimony is just another story" (ibid.: 149). Thus the symbolic power of the Holocaust has been successfully contained in the Diasporic space-time context in which it occurred, distancing it from the actual lives of contemporary Israeli teenagers. 


\section{Bodily Remains and Accessories}

Displays of relics, human bodily remains and accessories are a highly charged, ritual feature of the in situ Holocaust tour, documented by repetitive sequences in video recordings and websites. As a planner of the U.S. Holocaust museum records, confronting relics in situ: "Here the artifacts carried a terrible immediacy.... [T] he demands they made on a visitor were overwhelming.... I was stunned by the power of the[se] ruins and artifacts" (Linenthal 1995: 162). Judging from the evidence, the relics' symbolic function differs for MOL and Masa participants. MOL evidence communicates strong responses to displayed relics and accessories, ranging from sorrow to horror to reverence (Shevelev and Schomer 1996: 32). Apparently, the relics function metonymically as victims in the symbolic ritual of replacement, visually represented in a video sequence of shoes and other relics, spliced with shots of the youthful MOL participants walking through Auschwitz (Marsz Źywych Oświęcim 2008). Expressions of communion with the "huge mound[s] of human ash" through contemplation are especially prevalent in MOL documentation (Shevelev and Schomer 1996: 55, 74, 114).

James Young argues that human relics viewed in situ "...collapse the distinction between themselves and what they evoke," (Young 2004: 259) a comment reflecting MOL experience. Here a symbolic collapse between the living and the dead occurs in a twofold ritual process, prompted by contemplation of the relics and communion with their sacred energy. First, the relics metonymically replace absent Jewish bodies, attested thus: "Which shoes liked to walk? Which shoes liked to dance?" (Shevelev and Schomer 1996: 33). Then, as authentic symbols, the relics provoke collective assimilation of their sacred "mana" (a transcendent collective force uniting members of a society (EFRL: 196-200). Thus, the identity of the Jewish victims inherent in the relics, is assimilated into the living pilgrims, effecting symbolic replacement and revitalizing the sacred energy of the present Jewish collective. Concerning Masa, Feldman stipulates the same hierarchy of authenticity for relics as for sites, since only relics that invite sensory stimulation function as authentic symbols (Feldman 2008: 89), notably, the mounds of shoes and ashes at Majdanek, to which she devotes over eight pages of description (ibid.: 164-172). The relics displayed in the Auschwitz I museum merit a scant paragraph, since Masa participants deem them inauthentic due to lack of direct accessibility to the senses (ibid.: 142). Feldman hardly mentions the mounds of women's hair, singled out as an exceedingly impressive symbol in all other documentation. Young Israelis, apparently, can only experience symbolic authenticity in the presence of Majdanek's three 
barracks full of "moldy and smelly [rotting] shoes," evoking the horror of the camps through intensive olfactory and tactical sensation (ibid.: 167-169). Response to the mounds of shoes and ashes illustrates the process of distancing the Israeli present from the Diaspora past. To Masa pilgrims, they represent the "...the total annihilation of individual identity" that took place in the Diaspora, thus the finality of physical death (ibid.: 168) through a sense of "horror and fear at the site" (ibid.: 172).

\section{The U.S. Holocaust Museum}

While the Auschwitz-Birkenau complex is experienced as an extension of the events commemorated, the U.S. Holocaust Museum affirms the distance between Nazi racist atrocity and the benign tolerance of American pluralism (Young 2004: 267; Cole 1999: 150-158). The Museum opened in 1993, one of many such memorials and museums inaugurated in the late twentieth century (Young 2004; Holtschneider 2011). The Museum's founders had conscious ideological goals specific to the American context, intending the "moral lessons" learned from their "educational" presentation of Nazi genocide to have "universal significance" in a "pluralistic, multiethnic society" (Weinberg and Elieli 1995: 19) Indeed, the first Museum catalogue opens with a paean to American freedom and honesty: "Only in a democracy could a governmental museum include in its presentation, beside the well-deserved recognition and praise, such harsh self-criticism (for not proactively helping Jewish wartime refugees)" (ibid.: 18; Linenthal 1995: 255-272).

The Museum's planners aim to transform the visit of even the casual tourist into a pilgrimage prompting sacred experience. Accordingly, the "moral responsibility" of the Museum's founders and planning team made it "...a site of pilgrimage soon after it opened its doors to the public," in which "[t]housands of people...[were] confronted with images" prompting ".. an experience similar to that of pilgrims walking together to a sacred place" (Weinberg and Elieli 1995: 18). One device intended to sacralize visitors' experience is the practice of assigning them ID cards bearing the name of Holocaust victims (ibid.: 2; Cole 1999: 161-162). The ID card strategy can be understood as an attempted ritual of replacement, in which the living represent the dead. However, while this practice may well be personally significant to individual visitors, the ID card is not an authentic symbol, since it neither marks adherence to a social collective nor has any empirical connection between it and what it represents.

To refute Holocaust deniers, an obsession with authenticity permeated the construction and planning of the U.S. Holocaust Museum and 
its exhibits, which demanded not only historical accuracy, but making the museum experience as much as possible like the experience of actual Holocaust sites in Eastern Europe (Weinberg and Elieli 1995: 153). The Museum building was designed to mimic the architecture and building materials of actual Holocaust sites (ibid.: 24-48; Linenthal 1995: 72-108, 137-139, 168-170). Thus, facsimile casts of original iconic architectural features were integrated into the Museum's structure: a remnant of the Warsaw Ghetto wall and Auschwitz's Arbeit Macht Frei gate (Weinberg and Elieli 1995: 57; Linenthal 1995: 151-152). While reconstructed historical objects dubbed by the oxymoron "authentic reproduction" are deemed sufficiently authoritative for display in most American historical sites (Bruner 1994), reproduction of, or interference with, Holocaust artifacts is problematic (Coles 1994). Since all artifacts on exhibit had to be historically authentic (Weinberg and Elieli 1995: 29, 57), their collection, restoration and maintenance is a strenuous process involving international diplomacy (Gera 2012). Agreements were made with European governments for the loan of authentic Holocaust artifacts: a Danish boat involved in the rescue of Jews to Sweden, a Polish train car that carried Jews to Treblinka, and concentration camp relics such as bunks, shoes, personal accessories and women's hair (ibid.: 59, 68; Linenthal 1995: 210-211).

That the requirement for authenticity is in some way extreme or extraordinary is evident in the sheer space allocated to the subject in the literature (Linenthal 1995: 140-192; Weinberg and Elieli 1995: 57-69; Cole 1999: 160-162). The proposed exhibition of women's hair generated significant controversy (Linenthal 1995: 158, 210-216). Durkheim notes the uncanny, sacred power of hair cut from the human body, (EFRL: 137-138) an observation confirmed by the fact that the hair was the only object whose display was highly contested by Museum planners. Proponents of displaying the hair felt it would impress museum goers with a level of authenticity achievable by no other artifact, evidencing the Nazis' atrocious reduction of Jewish bodies to a raw material commodity used for financial profit. Indeed, the harvested hair was sold by the kilogram to the German textile industry, to be manufactured into yarn and felt to make socks for U-Boat crews and employees of the railway (Linenthal 1995: 211). While bodily relics were considered appropriately displayed "at Auschwitz or Treblinka or Mauthausen," displaying them in Washington D.C. was deemed highly "offensive to the memory of the dead" by opponents (ibid.: 212-213). The Museum compromised, storing the hair and displaying its color photo (ibid.: 215-216).

The Museum's refusal to display actual bodily relics shows its selfacknowledged secondary status as a sacred site, a tacit recognition of 
the privileged authority of European Holocaust sites. Although the Museum's discourse promises a pilgrimage experience, the authentic objects on display remain historical artifacts rather than sacred relics (although some visitors might well experience them as such). Whatever power the displays have to symbolicaly reaffirm ideologies of pluralism, tolerance and democracy, the Museum defers to, and hence reaffirms the uniqueness of actual Holocaust sites, perhaps symbolically articulating an ideology of Jewish difference or exclusion.

\section{Conclusion}

While I believe the authentic symbol to be a general feature of Western modernity, it is especially prevalent in Holocaust representation and ritual experience. The insistence that effective Holocaust symbols require empirical/historical integrity can be understood as a compensatory cognitive response to Nazi racial ideologies and practices of genocide. The Nazi state, the first to be systematically founded on biopolitics in a full juridical and political sense (Agamben 1998: 148), considered "race" a biological fact; thus it reified an ethnic social identity, "Jewishness," into an empirical, biological reality. Correspondingly, the symbolic language negotiating this conflation of the social and the biological reifies the symbol by demanding its authenticity. Moreover, during the Holocaust, distinct Jewish social groups were desacralized, in the Durkheimian sense, by reducing entire communities to hoards of unorganized individuals in ghettos and camps, individuals whose bodies were further reduced to constituent waste matter (ashes, bone) or commercial commodities (hair, gold teeth) through organized extermination. That is, the Nazis did not only exterminate millions of Jewish individuals, but entire Jewish collectives. While the sacred collective of Judaism survived Hitler, thousands of distinct Jewish communities have forever perished. Perhaps only authentic symbols can ritually commemorate and perpetuate the irrevocable loss of once thriving Jewish corporate social units with their own unique identities.

Durkheim's "ritual of pain," described above (EFRL: 320), may also account for the requirement of the authentic symbol in Holocaust ritual. While the experience of ordeal, or ritual of pain, predominates in the Masa tour, it is also evident in the MOL tour in a different configuration. Martyrdom is a special, extreme case of the ritual of pain; the individual martyr dies voluntarily to strengthen the social (ideological) life of her collective. While Nazi genocide was never experienced as martyrdom for its Jewish victims, who did not die voluntarily, their deaths have as- 
sumed symbolic martyrdom status for many Jews of the Diaspora striving to make the Holocaust meaningful. Since the actual victims did not suffer voluntarily, a compensatory shift enables the MOL pilgrims to do so in their stead by experiencing a voluntarily, disembodied "ritual of pain by proxy," demanding emotional rather than physical pain. The symbolic force of the real pain of dead Holocaust victims is thus transferred to the living MOL participants, a transference which can only be effected by authentic symbols, actual sites and relics. Thus, the physical pain suffered by Jewish Holocaust victims energizes a transcendent web of the Diasporic Zionist collective identity, rather than remaining an inert historical narrative of human suffering. The Holocaust tour as ritual of pain has different ends in the Masa tours, namely, ideological preparation for the duties of military service, involving anticipated actual bodily pain, trauma and possible death in the defense of the State. While some of the Diasporic MOL participants may well emigrate to Israel and serve in its armed forces, nearly all of the Masa participants are sure to do so in the very near future. Perhaps Masa's enhanced need for direct sensory experience and empirical authenticity reflects this reality, preparing Israeli teenagers for a near future, which may well require loss of actual life or limb.

The requirement for authenticity for effective response to the Holocaust has been criticized as problematic in light of the fact that the relics, as well as authentic sites themselves, are decaying and aging. Holocaust survivors are dying out (Cole 1999: 113; Rundle 2007). Certainly, as the historical distance from the Holocaust grows it will be remembered in different ways and provoke new ritual experiences. These changes will have to do not with our factual knowledge, but with quixotic, intangible and complex forces of society and with the "obscure relations" between its empirical and symbolic aspects, that is, between individual and collective consciousness (EFRL: 227). As Durkheim correctly observes: “...[S] ociety...[will remain] a system of active forces - not a nominal being and not a creation of the mind" (EFRL: 448). Currently, Western societies and their constituent communities increasingly require authentic symbols to stimulate ideological cohesion. Why this is so remains beyond detailed discussion here. I believe, however, that it has much to do with a transformation of what Durkheim calls the "sui generis synthesis of individual consciousnesses" (EFRL: 426) in the context of contemporary national and trans-national social and ideological allegiances (Blumer 2011). 


\section{REFERENCES}

Agamben, Giorgio. 1998. Homo Sacer: Sovereign Power and Bare Life. Stanford, CA: Stanford University Press.

Anderson, Benedict. 2006 [1983]. Imagined Communities: Reflections on the Origin and Spread of Nationalism. London: Verso.

Auschwitz Museum Exhibits. Scrapbookpages. Last modified July 29, 2009. (accessed February 9, 2012) http://www.scrapbook.com/auschwitzscrapbook/tour/Auschwitzl /Auschwitz 11.html.

Baldwin, Frank and Richard Sharpley. 2009. Battlefield tourism: bringing organized violence back to life. Pp 186-206 in Richard Sharpeley and Philip R. Stone, eds., The Darker Side of Travel: the Theory and Practice of Dark Tourism. Buffalo, NY: Channel View Publications.

Beech, John. 2009. Genocide tourism. Pp 207-223 in Richard Sharpely and Philip R. Stone, eds., The Darker Side of Travel: the Theory and Practice of Dark Tourism. Buffalo, NY: Channel View Publications.

Benjamin, Walter. 2008 [1936]. The work of art in the age of its technological reproducibility: second version. Pp19-55 in Michael Jennings, Brigid Doherty and Thomas Levin eds., The Work of Art in the Age of Its Technological Reproducibility, and Other Writings on Media. Cambridge, MA: Belknap/Harvard University Press.

Biale, David. 2007. Blood and Belief: the Circulation of a Symbol between Jews and Christians. Berkeley: University of California Press.

Blumer, Nadine. 2011. "Am yisrael chai! (the nation of Israel lives!)": stark reminders of home in the reproduction of ethno-diasporic identity. Journal of Ethnic and Migration Studies 37 (November): 1331-1347.

Bodemann, Y. Michal and Hyla Korn. 2006. Holocaust commemoration as a popular religious movement? The case of Holocaust Week in Toronto. Journal of Modern Jewish Studies 5 (March): 109-130.

Brueggman, Rudy. A Trip to the Camps. Last modified June 2001. (accessed February 10, 2012). http://www.rudyfoto.com/hol/campstory.html.

Bruner, Edward M. 1994. Abraham Lincoln as authentic reproduction: a critique of postmodernism. American Anthropologist 96.2: 397-415.

Cole, Tim. 1999. Selling the Holocaust: from Auschwitz to Schindler. New York: Routledge.

Durkheim, Émile. 1995 [1912]. The Elementary Forms of Religious Life. Ed. and trans. Karen E. Fields. New York: Free Press.

Eilberg-Schwartz, Howard. 1992. The People of the Body: Jews and Judaism from an Embodied Perspective. Albany: SUNY Press.

Feldman, Jackie. 2008. Above the Death Pits, Beneath the Flag: Youth Voyages to Poland and the Performance of Israeli Identity. New York: Berghahn Books. 
Fields, Karen E. 1995. Translator's Introduction. Pp xvii-lxxiii in Émile Durkheim, The Elementary Forms of Religious Life. New York: Free Press.

Fournier, Marcel. 2007. Émile Durkheim: 1858-1917. Paris: Arthème Fayard.

Friedland, Roger. 2005. Drag queens at the totem ball: the erotics of collective representation in Émile Durkheim and Sigmund Freud. Pp239-273 in Jeffrey C. Alexander and Philip Smith, eds., The Cambridge Companion to Durkheim. Cambridge: Cambridge University Press.

Gera, Vanessa. 2012. Auschwitz relic has Poland, U.S. at odds. Associated Press, in: The Courier-Journal, February 24, 2012, A6.

Grunfeld-Grossman, Lisa. 2006. An Investigation of Florida High School Students" Holocaust Experiences and their Lived Experiences as Participants in the "March of the Living." $\mathrm{PhD}$ in Education Dissertation. Barry University.

Hanks, Patrick, ed. 1986. Collins Dictionary of the English Language. $2^{\text {nd }}$ edition. London: Collins.

Horne, David. 1984. The Great Museum: the Re-Presentation of History. London: Pluto Press.

Holtschneider, K. Hannah. 2011. The Holocaust and Representations of Jews: History and Identity in the Museum. New York: Routledge.

Jennings, Michael. 2008. Editors' introduction. Pp 1-18 in Michael Jennings, Brigid Doherty and Thomas Levin eds., The Work of Art in the Age of Its Technological Reproducibility, and Other Writings on Media. Cambridge, MA: Harvard University Press.

Linenthal, Edward T. 1995. Preserving Memory: the Struggle to Create America"s Holocaust Museum. New York: Viking.

Lipstadt, Deborah. 1993. Denying the Holocaust. New York: Free Press.

MacCannell, Dean. 1999 [1976]. The Tourist: A New Theory of the Leisure Class. Los Angeles: University of California Press.

March of the Living International. N.d. (accessed February 9, 2012). http://www. motl.org.

Marsz Źywych Oświęcim - March of the Living 2008. Polish Friends of Israel. YouTube. Last modified May 3, 2008. (accessed February 12, 2012). http://www.youtube.com/watch?v=MAV-XRLOf4s.

Patranka, Vivian M. 1997. Situating history and difference: the performance of the term holocaust in public discourse. Pp 54-73 in Jonathan Boyarin and Daniel Boyarin, eds., Jews and Other Differences: the New Jewish Cultural Studies. Minneapolis: University of Minneapolis Press.

Rothberg, Michael. 2000. Traumatic Realism: the Demands of Holocaust Representation. Minneapolis: University of Minneapolis Press.

Rundle, Guy. 2007. Let the death camps die. Spiked 12. (accessed February 15, 2012). http://www.spiked-online.com. 
Sharpely, Richard and Philip R. Stone. 2009. (Re)presenting the macabre: interpretation, kitschification and authenticity. Pp 109-128 in idem. eds., The Darker Side of Travel: the Theory and Practice of Dark Tourism. Buffalo, NY: Channel View Publications.

Shevelev, Raphael and Karine Schomer, eds. 1996. Liberating the Ghosts: Photographs and Text from the March of the Living. Portland, OR: Lensworks Publishing.

Shilling, Chris. 2005. Embodiment, emotions and the foundations of social order: Durkheim's enduring contribution. Pp 211-238 in Jeffrey C. Alexander and Philip Smith, eds., The Cambridge Companion to Durkheim. Cambridge: Cambridge University Press.

Weinberg, Jeshajahu and Rina Elieli. 1995. The Holocaust Museum in Washington. New York: Rizzoli.

Weintraub, Gary. March of the Living: the Only Choice. March of the Living International. (accessed February 2, 2012). http://www.motl.org/alumni/ alumni-mol-only0choice-weintraub.htm.

Young, James E. 2004. Holocaust museums in Germany, Poland, Israel and the United States. Pp249-274 in Konrad Kwiet and Jürgen Matthaüs eds., Contemporary Responses to the Holocaust. Westport, CT: Praeger.

\section{ACKNOWLedgments}

I warmly thank Karen E. Fields for her encouraging electronic exchange, and to the editors and anonymous reviewers at the Canadian Journal of Sociology for their careful reading and improving suggestions.

Natalie C. Polzer is Associate Professor of Humanities at the University of Louisville, where she teaches Jewish Studies, Women/Gender Studies and Theory of Religion. Her research focuses on gender, purity and impurity, sensory perception and disgust in rabbinic literature and contemporary Jewish practice. Her work has appeared in the Australian Journal of Jewish Studies, Women in World Religions and in the Association for Jewish Studies Review. She is currently authoring a volume on Mishnah Tractates Avot and Edduyot for the Feminist Commentary on the Babylonian Talmud Series (Mohr Siebeck).

$\underline{\text { Natalie.Polzer@,louisville.edu }}$ 